IRSTI 03.09.31

\author{
Abdukadyrov N.M. ${ }^{1}$, Yerkenkyzy A. ${ }^{2}$ \\ ${ }^{1} \mathrm{Ph} . \mathrm{D}$, e-mail: nurjigit.85.kanuni@gmail.com \\ ${ }^{2}$ master-student, e-mail: ms.yerkenkyzy@mail.ru \\ al-Farabi Kazakh National University, Kazakhstan, Almaty

\section{INTEGRATION PROCESSES \\ IN THE FINANCIAL SPHERE BETWEEN \\ THE OTTOMAN EMPIRE AND FRANCE \\ (the second half of the XIX century)}

\begin{abstract}
One of the main indicators of the strength and power of world empires in the XIX century is the development of the economic sphere; each empire applied the prospect of development of its economy. To this end, the strengthening of foreign trade, the development of industry, the banking and financial-credit sectors were taken into account, since the search for colonies and tax collection from underdeveloped countries was no longer so important. In addition, world empires have come closer to each other in the economic sphere, and also established strong ties in other sectors of economy. Relations in the financial sector, considered one of the main areas of the economy in the second half of the XIX century, had a particularly important role in the international economy. Such ties in the financial sphere were established between the Ottoman Empire and France, which was the main player in the European economy. This scientific article discusses the history of cooperation in the financial sphere between the Ottoman Empire and France in the second half of the XIX century. A scientific analysis will be conducted regarding financial integration between the two empires, as well as its development process and directions. Also, one of the main objectives of the article is the study of economic projects implemented in the credit sector, their progress and results.
\end{abstract}

Key words: Ottoman Empire, France, Finance, Credit, Bank, Economy, Ottoman Bank.

\author{
Абдукадыров Н.М. ${ }^{1}$, Еркенқызы Ә. ${ }^{2}$ \\ 1Ph.D, e-mail: nurjigit.85.kanuni@gmail.com \\ 22 курс магистранты, e-mail: ms.yerkenkyzy@mail.ru \\ әл-Фараби атындағы Қазақ, ұлттық, университеті, Қазақстан, Алматы қ.
}

Осман империясы мен Франция арасында

қаржы саласындағы интеграциямық процестер

(XIX ғасырдың екінші жартысы)

XIX ғасырда әлемдік империялардың күш-қуатын айқындайтын басты көрсеткіштердің бірі ол - экономикалық саланың Аамуы болып, әр империя өз экономикасын дамыту перспективасын жасады. О^ үшін ендігі кезекте сыртқы сауданы күшейту, өндірісті өркендету, банк және қаржы-несие салаларын дамыту басшылыққа алынды, өйткені, бұрынғыдай отарлар іздеп, әлсіз халықтардан салық жинау аса маңызды болмай қа^ды. Сонымен қоса, әлемдік империялар бір-бірімен экономикалық салаАа жақындаса түсті және оның әр түрлі бағыттары бойынша тығыз байланыстар орнатты. XIX ғасырдың екінші жартысында экономиканың басты бағыттарының бірі саналған қаржы саласындағы байланыстар халықаралық экономикала аса маңызды орын иеленді. Осындай қаржы саласындағы байланыстар еуропалық экономиканың үлкен бөлігін уысында ұстаған Франция мен Осман империясының арасында да орнаты^ды. Ұсынылып отырған ғылыми мақалада XIX ғасырдың екінші жартысында Осман империясы мен Франция арасында қаржы саласындағы орнатылған ынтымақтастық тарихы қарастырылады. Екі империя арасындағы қаржы саласындағы интеграция мен оның даму үлерісі және бағыттарына ғылыми талдау жасалады. Сондай-ақ, кредит саласында өзара жүзеге асырған 
экономикалық жобалары және оның барысы мен нәтижелерін зерттеу мақаланың басты міндеттерінің бірі саналады.

Түйін сөздер: Осман империясы, Франция, Қаржы, Несие, Банк, Экономика, Осман банкі.

\author{
Аблукадыров Н.M. ${ }^{1}$, Еркенкызы А. ${ }^{2}$ \\ 'Ph.D, e-mail: nurjigit.85.kanuni@gmail.com \\ ${ }^{2}$ магистрант 2 курса, e-mail: ms.yerkenkyzy@mail.ru \\ Казахский национальный университет имени аль-Фараби, Казахстан, г. Алматы
}

\author{
Интеграционные процессы в финансовой сфере \\ между Османской империей и Францией \\ (вторая половина XIX века)
}

\begin{abstract}
ОАним из главных показателей силы и мощи мировых империй в XIX веке являлось развитие экономической сферы. КажАая империя выдвинула перспективу развития своей экономики. А^я этого было принято в особое внимание укрепление внешней торговли, развитие промышленности, банковской и финансово-кредитной сфер, так как поиски колоний и собирание налогов с колоний и полуколоний уже стало не так важным. Кроме этого, мировые империи сблизились Аруг с Аругом в экономической сфере и установили крепкие связи в других ее направлениях. Связи в финансовой сфере, считавшиеся одной из основных направлений экономики во второй половине XIX века, играли особенно важную роль в международной экономике. Такие связи в финансовой сфере были установлены между Францией, являвшейся главным игроком в европейской экономике, и Османской империей. В Аанной научной статье рассматривается история сотрудничества в финансовой сфере между Османской империей и Францией во второй половине XIX века. Бы^ провеАен научный анализ развития и направлений интеграции в финансовой сфере между Авумя империями. Также, одной из основных задач статьи является изучение экономических проектов, реализованных в кредитной сфере, процесс их реализации.

Кмючевые слова: Османская империя, Франция, финансы, кредит, банк, экономика, Османский банк.
\end{abstract}

\section{Introduction}

In the XIX century, the economic situation of the Ottoman Empire began to deteriorate. From the 30 s to the 40 s of the XIX century the Ottoman Empire began to realize that the economy of the Empire lags far behind the economies of European countries. First of all, if we consider the economic situation of the two countries, we can see that the economy of the Ottoman Empire was very different from the economy of France. In trade relations between two countries, the French one dominated. The main examples of this were that the French were selling the products to the Ottoman Empire at a high price. And the Turks traded goods in the form of raw materials, and most of the sold goods were agricultural products. Because the Ottoman Empire did not have any branch of industry to produce finished products, which were attractive for European markets. In short, the Ottoman trade could not resist French trade. On this basis, the French economy, based on industrial production, gradually developed, and the economy of the Ottoman Empire, based on the agricultural sector, conversely declined. In this regard, attention should be focused on the external and internal socio-economic factors that influenced the gradual disintegration of the Ottoman economy.

\section{Materials and methods}

Materials related to the topic are archival materials, collections of documents and research papers. The main ones are archival materials, in the Ottoman Archive in the İrade Hariciye fund (Foreign Decrees) a number of documents relating to the political and economic relations of the Ottoman Empire and France are stored (İrade Hariciye). The fund preserved the agreements concluded between European countries, including France and the Ottoman Empire, as well as the decrees of the Ottoman government concerning foreigners. Along with this, the department of Dîvân-1 Hümâyûn preserved a list of many business papers, giving the opportunity to explore the history of political and diplomatic relations between the Ottoman Empire and France. (Dîvân-1 Hümâyûn).

Moreover, one can analyze the French materials on the topic. One of the materials published in France is a four-volume collection of documents regarding the history of the foreign policy of the Ottoman Empire. Gabriel Noradounghian compiled this collection of documents (Recueil D'actes 
Internationaux de L'Empire Ottoman - Acts on the International Relations of the Ottoman Empire). This collection provides information about the economic treaties concluded between the Ottoman Empire and France (Noradounghian, 1978).

In the works of French historians about the economic relations between the Ottoman Empire and France, the history of the economic relations of the empire with France are taken into particular attention. The reason for such increased interest from French scientists was the dominant role of France in the economy of the Ottoman Empire in the XIX century. The main scientific object in the research work of French historian André Autheman (Autheman, 1996) is the influence of France in resolving the financial problems encountered in the Ottoman Empire. The research work of the historian A. Du Velay (Velay, 1903) is one of the valuable scientific materials. The researcher published a voluminous work titled «Financial History of Turkey.» He explains the main reasons for the decline in the empire by the financial crisis in the country, and indicates the economic activity of French financial groups in improving the condition. The historian J.Peliise de Rausas, who studied the economic history of the Ottoman Empire, in his work drew conclusions regarding the concluded financial agreements between the Ottoman Empire and France (Rausas, 1902), as well as their economic history. And also, there is a research paper by A. Bilotti on this topic (Bilotti, 1909). It contains scientific findings regarding the assistance of French financial groups in the establishment of the Ottoman Empire's imperial bank. Among French historians who studied the history of political and economic relations between the Ottoman Empire and France in the XIX century J.Thobie plays an important role (Thobie, 1973). The researcher devoted his main works to the study of the economic policy of France in the Ottoman Empire in the XIX century; in these works, he considers the relations of the two states in the financial sphere with the help of exact quantitative indicators. The studies of the Turkish historian Halil Inalcik deal with the Ottoman-French, Ottoman-European economy, which, in turn, are the main materials of the topic (Inalcik, 1997). In the studies of the historian E. Eldem, special attention is paid to the relations of the Ottoman Empire with France (Eldem, 1999). And also, in the studies of Ş. Pamuk and H. Kazgan the Ottoman-French financial (Pamuk, 1988) and economic relations are described (Kazgan, 2014).

In this article, the works, fundamental theories and conclusions of foreign scientists have been applied. In writing the article such methods of historical science, as historical compatibility, historical and typological, description, scientific analysis and synthesis, historical systematization were used. In addition, during the narration of historical events in the consideration of political and historical processes additional scientific methods were used. For the study of the topic modern methodology of historical sciences is taken as a basis. In the study of the economic relations of the Ottoman Empire and France, quantitative methods of historical and mathematical sciences are also used.

\section{Results and discussion}

As one of the main reasons of external economic factors we can show that the inappropriate actions of the administration in the field of trade led to the lack of foreign trade in the Ottoman Empire. The government of the Ottoman Empire believed that measures such as setting industrial production and the conversion of light industry products into agricultural products would increase exports. The Ottoman government decided that the capitulations it had made for these actions were correct. And such actions were very effective for the mercantile peoples of Europe. The capitulations were not enough for Europeans looking for a market to produce their products, so they asked for lower tariffs on free trade, as well as allowing traders to buy and sell different types of goods. In 1838-1839, the contracts concluded with England, later with France, and over the past five years with European countries were mostly resolved in favor of the European countries. Thus, the Ottoman Empire became the "common market» of the Europeans (Kasaba, 1988:20). In addition, the failure of external wars, by contrast, led to increased military spending, reduced tax revenues, capitulation, reduced customs duties and a foreign trade deficit after 1838 trade agreements with England and other European countries. In 1850, the budget deficit was $£ 1$ million. To control the budget deficit the Ottoman state contracted debts from the Galata bankers. However, such an economic crisis could not be prevented by borrowing funds from Galata bankers and European financial institutions in the Ottoman Empire. The Crimean war, which began with Russia in 1853, was also a burden to the Ottoman Empire, causing the country to face a number of social and economic problems. Although, the Ottoman Empire was on the side of the winner countries in the war, it was unable to make a large profit. The consequences of the Crimean war were limited by geopolitical 
problems. The Crimean war (1853-1856) had a serious impact on the Ottoman state economy. The financial costs of the war reached 11 million pounds. To overcome this crisis, it was considered to incur a debt from European countries. Because there was no other choice apart from borrowing from outside (Kazgan, 2014: 70).

The internal socio-economic factors that led the Ottoman Empire to borrow from European countries: long period of the «timar» system in the Ottoman Empire and the late collection of taxes, the rise of corruption among the governors - ultimately all undermined the reputation of the government. Reduced control over Central government tax collection also led to a reduction in tax revenues. Failures in external wars weakened the economy of the state. The Ottoman government carried out military, political and economic reforms to overcome this. And these reforms led to a deficit in the state budget. In 1854, the internal debt of the Ottoman Empire reached 15 million pounds, and the problem of the budget deficit became the main problem of the state. There were other economic problems in the country. At the same time, population growth, the collapse of borders as a result of many wars, the reduction of income due to the reduction of trade routes (transit goods) increased the economic crisis in the Ottoman Empire. Such economic, political, social and military factors accelerated the countrys external borrowings (Y1lmaz, 2002: 188).

These economic crises, which began in 18401850, forced the Ottoman Empire to borrow from European countries. One of the states that granted credit to the Ottoman Empire was France. France is characterized as the country that granted the largest loan to the Ottoman Empire from 1854 until its fall. Since credit became one of the main branches of the economy, the Ottoman Empire borrowing from France may be one of the most important topics for the economy of the Empire. The fact that the Ottoman Empire borrowed funds from France shows the high level of economic relations between two countries. In order to borrow from France and other European countries, the Ottoman Empire government needed banking services. In short, it was necessary to create an imperial state bank in the Ottoman Empire. France had a special assistance in establishing the imperial level bank in the Ottoman Empire (Biltekin 2009: 30-31). In this regard, if we take into consideration the banking in the Ottoman Empire and its development issues, banking activities in the Empire began much later than in Europe. The underdevelopment of banking in the Ottoman Empire until Tanzimat period was caused by the fact that interest rates were banned in Islam and that the people of the Empire were involved in military affairs, public administration and industry. Non-muslims were often involved in trade mediation, excessive interest rates and banking. Before that, the Ottoman merchants and merchants of Galata played a major role in the financial sphere of the Empire. These bankers mainly focused on external financing from Europe and lent to local entrepreneurs. At the same time, they were engaged in lending to the state and began to improve the living conditions of the population, but did not achieve any results. The reason was that they did not have enough money to provide the entire financial sector of the Empire. The gradual development of the banking industry in the Ottoman Empire was directly influenced by French and British bankers. They supported local merchants and gave them loan. Because in this period, namely in the second half of the XIX century, the development in foreign trade was much more extensive than in industry. Foreign trade played an important role in the recovery and disintegration of the economy. This effect of foreign trade in the economy led to the development of banking and the growth of financial centers. European trading exchanges had a great influence on the work of financial centers and banks (Takan 2001: 4).

Thus, between the beginning of the XVIII and the beginning of the XIX century economic relations between the empires were mainly focused on trade relations, since the second half of the XIX century good relations between the states in the fields of finance, banking and industry were established. During this period, various contracts for these sectors of the economy were signed between the Ottoman Empire and France. Before we consider the financial and credit relations between the Ottoman Empire and France, it should be noted that France was the first country that helped to establish a bank in the Ottoman Empire. French entrepreneurs, together with representatives of the British financial community, contributed to the creation and establishment of the first bank in the Ottoman Empire in 1847 (Bank-1 Dersaadet - Banque de Constantinople), and helped its further work. Thus was created the first state bank in the Ottoman Empire. Paris financial groups together with London businessmen deposited more than 130 million pounds of paper money at the opening period. All this was aimed at strengthening the Empire's relations with foreign countries in the field of trade and finance (Eldem, 1999: 23). Relations between French financiers and large and small banks established in the Ottoman Empire continued into the following period. And 
in the 50s of the 19th century, such contacts in the banking sector were held at the interstate level. After the end of the Crimean war in 1856, the Ottoman Sultan I. Abdulmejid issued a decree «Islahat firman» calling for the establishment of a state bank in the Ottoman Empire, and requested the government to impelement it. These actions of the government were supported by Galata ${ }^{1}$ bankers (Bayraktar, 2002: 77-78). With the financial support of British and other European financial groups, the Ottoman Bank was established in June 1856 for the first time in history. The decision to establish the Ottoman Bank was signed by diplomats led by British diplomat Henry Laird and representatives of Glane, Co financial groups.

Although the Ottoman Bank was established in the Ottoman Empire, it was unable to solve the financial problems that existed in the Empire. Financial problems in the Empire gradually escalated. The issue and circulation of paper money in the Ottoman Bank were related to foreign financial groups. Among them, in the establishment of the Ottoman Bank the dominant role was belonged to the British financial group. Due to the fact that most of the shares were concentrated in the hands of British and European capitalists, the state significance of the bank was at a low level. The Ottoman government intended to raise the state level of the Ottoman Bank, print currency and have close ties with the people. To this end, the Ottoman government preferred to change the status of the Ottoman Bank. In 1860, the Ottoman Bank was reformed and questions were raised about raising the state status, and on 15 January 1863 the Ottoman government decided to transform the «Ottoman Bank» into the «Bank of the Ottoman Empire». On February 6, 1863, the Sultan of the Ottoman Empire Abdulaziz announced a special firman about the establishment of the Bank of the Ottoman Empire. On this basis, «the Ottoman Bank», founded in 1856, was abolished seven years later. Instead, as a result of many contradictions, a new bank «La Banque Imperial Ottoman» was created, which became the state property of the Empire. France provided a lot of financial support for the restoration of the state Bank of the Ottoman Empire. French financial groups worked especially on new banking services and new reforms in lending of the imperial Bank (Autheman, 1996: 30-31). This is the main reason why the imperial Bank is mentioned in French in foreign documents. French

${ }^{1}$ Galata - Economic district of Istanbul situated in the European part of the city. The largest trade and financial centers operated here at that period. investors regularly accepted requests from the Ottoman Empire for a loan. One of the most important economic measures provided by French financial institutions to the Ottoman Empire Bank was assistance in printing paper money in the imperial Bank of Ottoman Empire since 1862. Since then, French financial groups helped to print currency in the imperial Bank of the Ottoman Empire and recognize it as an international currency. These steps in banking became one of the most important events in the economic history of the Ottoman Empire. The attraction of capital from France to the imperial Bank of the Ottoman Empire and the assistance of French financial circles in the creation of the imperial Bank are characterized by a high level of economic relations between the Ottoman Empire and France (Velay, 1903: 260-266).

As for the borrowing of money from France by the Ottoman Empire, this is a history of separate economic relations. As we have already noted, France was the largest borrower in the Ottoman Empire in the era of destruction, which since the Crimean war of 1854 until the First World War lent to the Empire. The Bank of the Ottoman Empire had many financial funds of French financiers. That's why France provided money to the Ottoman Empire through the Ottoman Bank. The Ottoman Empire borrowed from France several times with the help of this Bank and earlier from European banks operating in Istanbul. The first debt from France was acquired in 1854, and the main reasons for this were military needs during the Crimean war of 1853-1856. The Ottoman government borrowed funds from the French financial community and entrepreneurs in accordance with an intergovernmental agreement with France. The Ottoman Empire borrowed the largest amount of debt from the French. The main reasons for contracting a debt by the Ottoman Empire from France and European countries was to prevent the above-mentioned economic crisis (Açba, 2004: 54-55).

However, borrowing of the Ottoman Empire from France was not easy for the Turks. Over time, the Ottoman Empire fell into economic dependence on France. France, like other European states, invested its capital in the Ottoman Empire, crediting the Ottoman Empire, and exported the Empire's raw materials to Europe. Europeans bought this raw material at a cheaper price, made products from it and sold to the Turks at a higher price. In the provinces of the Ottoman Empire French monopolies were opened, especially in the Near East and Africa. The role of France in the Ottoman Empire was increased. The implementation of such economic projects of 
France in the Ottoman Empire was prevented by the British. Because after the conclusion of the trade agreement Balta Liman between the Ottoman Empire and England in 1838 Britain became the defender of the Ottoman Empire (Kütükoğlu, 1974) from foreign political actors. However, France, Russia, Great Britain and Austria did not strongly support the division of the territory of the Ottoman Empire within the «Eastern question». The main economic goal of the French in establishing economic relations with the Turks was the extraction of the ample raw materials of the Ottoman Empire at low prices. To this end, the French authorities appealed to the Ottoman government for a new trade deal.

The increase in foreign trade in the financial sector also contributed to the growth of financial ties between the countries. In short, the great trade agreement between the Ottoman Empire and France was concluded in 1740. A new major trade agreement between the two empires was concluded in 1861 . The contract consisted of eighteen chapters dealing mainly with trade issues. As already mentioned in the main articles of this agreement, the third paragraph of the agreement provides various benefits for French traders, including customs tariffs, the exit of goods from ports, security. The fourth article of the agreement states that French traders have the right to sell freely in all provinces of the Ottoman Empire. The fifth article of the treaty deals with the percentage of customs duties levied on French traders in the Ottoman Empire, where the export tax is reduced to 8 percent. According to the seventeenth article of the treaty, the treaty was concluded for twentyeight years. Upon expiry of the period, the contract could be changed according to the proposals of the parties. In accordance with article 18 of the trade agreement between the empires, goods produced in France were sold freely in all provinces of the Ottoman Empire (Önsoy, 1988: 134-135).

After this agreement, relations between the Ottoman Empire and France in all sectors of the economy rose to a high level. To stimulate foreign trade on the basis of the contract, as the first one, the French planned to send a channel to the East, through the land of Egypt to the Red Sea. These were plans for the construction of the future Suez Canal. In 1869, the French, together with other European countries, built the Suez Canal for the development of foreign trade. Through the canal, they developed foreign trade with the Ottoman Empire. However, soon the Suez Canal under the agreement of the Ottoman government and the ruler of the Egyptian prov- inces came under the control of Great Britain and the political significance of the canal increased in comparison with economic importance. However, in accordance with the decision of the international Convention adopted in Istanbul in 1888, the Suez Canal was used by all countries, and international trade was not stopped here. As a result, the Suez Canal remained a key economic zone for trade between the two countries.

In the 80 -th of the XIX century due to the inability to timely repayment of loans borrowed from France and other European countries, their growth increased, and the Ottoman Empire underwent a major economic crisis. In this regard, the treaty between the European and French capitalists and the government of the Ottoman Empire was signed in 1881. Accordingly, the percentage of loans was reduced and the terms of repayment were changed. In addition, a governmental agency (Düyun-u Umumiye) was established to monitor the repayment of loans. There were representatives responsible for funds paid to banks in England, France, Italy, Germany, Austria and Galata. After that, the Ottoman state continued to borrow money. England, France, Germany became the largest debt holders and investors in the Ottoman Empire, and their possessions in the Ottoman Empire increased. In 1881, France invested a total of 85 million francs in this state, which increased by 292 francs in 1895, and by 1911 this figure reached 511 million (Quataert, 1983: 19). These debts drove the Ottoman Empire to a standstill. As a result, the Ottoman Empire declared bankruptcy. The Empire became politically dependent on European empires as a result of external debt and internal economic crises and various barriers in domestic and foreign policy. At that time, the British Empire thought of the East territories of the Ottoman Empire. Similarly, by the end of the nineteenth century, France began to claim possessions of the Ottomans. France did not pose a political threat to the territories of the Ottoman Empire like Russia and the British Empire through foreign policy and economic pressure. However, the policy of world imperialism, in turn, forced France to attack the territorial integrity of the Ottoman Empire. Its main example was the unopposed establishment by France of a protectorate in 1881 in Tunis province of the Ottoman Empire. Such political actions of France towards the Ottoman Empire intensified at the turn of the 20th century, and the French subsequently contributed to the fall of the Ottoman Empire. 
Integration processes in the financial sphere between the Ottoman empire and France

Indicator of debts of the Ottoman Empire from France in the XIX century

\begin{tabular}{|c|c|c|c|c|c|c|}
\hline $\begin{array}{l}\text { Borrowed } \\
\text { time }\end{array}$ & \begin{tabular}{|c|} 
Amount of \\
borrowed funds
\end{tabular} & $\begin{array}{l}\text { Turkish lira- } \\
\text { denominated } \\
\text { debt }\end{array}$ & $\begin{array}{c}\text { Annual } \\
\text { percentage }\end{array}$ & $\begin{array}{l}\text { Group of brokers and } \\
\text { debt holders }\end{array}$ & Reasons for borrowing & $\begin{array}{l}\text { Financial resources } \\
\text { for debt settlement }\end{array}$ \\
\hline 1854 & $\begin{array}{l}\text { 3,3 million } \\
\text { francs }\end{array}$ & $\begin{array}{l}2,6 \text { million } \\
\text { turkish lira }\end{array}$ & $6+1$ & $\begin{array}{l}\text { Businessmen of lead } \\
\text { by Goldschmidt } \\
\text { (Paris) }\end{array}$ & $\begin{array}{l}\text { During the Crimean } \\
\text { War to buy weapons } \\
\text { and for repaying } \\
\text { financial losses }\end{array}$ & $\begin{array}{l}\text { Charges from Egypt } \\
\text { province }\end{array}$ \\
\hline 1860 & $\begin{array}{l}2,2 \text { million } \\
\text { francs }\end{array}$ & $\begin{array}{l}1,4 \text { million } \\
\text { turkish lira }\end{array}$ & $6+2$ & $\begin{array}{c}\text { French banker and } \\
\text { director of railway } \\
\text { company Mires }\end{array}$ & To repay internal debt & From land tax \\
\hline 1862 & $\begin{array}{l}8,8 \text { million } \\
\text { francs }\end{array}$ & $\begin{array}{l}5,9 \text { million } \\
\text { turkish lira }\end{array}$ & $6+2$ & Ottoman bank & $\begin{array}{c}\text { To repay domestic } \\
\text { loans and issuance of } \\
\text { paper money }\end{array}$ & $\begin{array}{l}\text { From the customs } \\
\text { duties in Istanbul }\end{array}$ \\
\hline 1863 & $\begin{array}{l}8,8 \text { million } \\
\text { francs }\end{array}$ & $\begin{array}{l}6,2 \text { million } \\
\text { turkish lira }\end{array}$ & $6+2$ & $\begin{array}{l}\text { Ottoman bank } \\
\text { and Credit Mobilier }\end{array}$ & $\begin{array}{c}\text { Received to repay } \\
\text { short-term loans and } \\
\text { budget losses }\end{array}$ & $\begin{array}{l}\text { Dues from silk, } \\
\text { olive and salt }\end{array}$ \\
\hline 1865 & $\begin{array}{l}6,6 \text { million } \\
\text { francs }\end{array}$ & $\begin{array}{l}4,3 \text { million } \\
\text { turkish lira }\end{array}$ & $6+2$ & $\begin{array}{l}\text { Ottoman bank and } \\
\text { Credit Mobilier }\end{array}$ & $\begin{array}{c}\text { Repayment of external } \\
\text { debt and budget deficit } \\
\text { adjustment }\end{array}$ & $\begin{array}{c}\text { Dues from mining } \\
\text { products produced } \\
\text { in the country }\end{array}$ \\
\hline 1877 & $\begin{array}{l}5,5 \text { million } \\
\text { francs }\end{array}$ & $\begin{array}{l}2,8 \text { million } \\
\text { turkish lira }\end{array}$ & 5 & $\begin{array}{l}\text { Ottoman bank and } \\
\text { Mills Klein, Co } \\
\text { named businessmen }\end{array}$ & $\begin{array}{l}\text { To spend military } \\
\text { expenditures in the } \\
\text { Russian-Turkish war } \\
\text { of } 1877-1878\end{array}$ & $\begin{array}{l}\text { Taxes from Egypt } \\
\text { province }\end{array}$ \\
\hline 1885 & $\begin{array}{l}1.012 .000 \\
\text { francs }\end{array}$ & & 7 & $\begin{array}{l}\text { Through the Ottoman } \\
\text { empire bank }\end{array}$ & Economic problems & $\begin{array}{l}\text { Taxes from railways } \\
\text { in Rumelia }\end{array}$ \\
\hline
\end{tabular}

\section{Conclusion}

In conclusion, in the second half of the nineteenth century, France was one of the countries that established strong ties with the Ottoman Empire. During this period, financial ties between the two countries covered most of the international economy. The Ottoman Empire was a close partner of France in the field of finance, and they became reliable partners in this field. In the Ottoman Empire, among other European countries France played a key role in the establishment of the imperial Bank, banking and financial affairs, foreign investment and the regulation of money circulation, the issuance of paper money and lending. France occupied a special place in the economic life of the Ottoman Empire. One of the main features was that France in the nineteenth century mainly developed economic relations with the Ottoman Empire, which contributed to its significant financial benefits. On this basis, French businessmen, bankers and financial circles came to the Ottoman Empire in the nineteenth century. The Ottoman government placed great trust in French financiers. France, on the other hand, became the country that provided the largest loan to the Ottoman Empire. However, since the French capitalists occupied most of the banking and financial industries in the Ottoman Empire, the Ottoman Empire did not even notice how it became economically dependent on France. The Ottoman economy was unable to cope with the French economy, which has grown much faster. The empire realised that it was unable to repay foreign loans to the French. This process continued with the economic downturn in the Ottoman Empire.

\section{References}

André Autheman. (1996). La Banque Impériale Ottomane. Paris.

A. Du Velay, (1903). Essai sur l'histoire financiére de la Turquie Paris.

BOA. Divân-1 Hümâyun Defteri DVN. NMH, 12/157

BOA. İrade Hariciye: 3647, 3784, 4974, 6736 , 6155, 6150, 6057 
Biltekin Özdemir. (2009). Osmanlı Devleti Dış Borçları 1854-1954 Döneminde Yüzy1l Süren Boyunduruk. Ankara.

Biliotti A. (1909). La Banque imperiale ottomane. Paris: Jouve,

Eldem E. (1999). Osmanlı Bankası Tarihi. İstanbul: Yurt Yayınları,

Inalcik Halil. (2006). Turkey and Europe History. İstanbul: Eren, York.

Kasaba R. (1988). The Ottoman Empire and the World Economy: The Nineteenth Century. Albany: State University of New

Kaya Bayraktar (2002). Osmanlı Bankasının Kuruluşuee, C.Ü. İktisadi ve İdari Bilimler Dergisi, Cilt 3, Sayı 2, S 71-88.

Kazgan Haydar. (2014). Galata Bankerleri. İstanbul, Tarihçi Kitabevi.

Kütükoğlu M. (1974). Osmanl1-İngliz iktisadi münasebetleri (1580-1838). Ankara: Türk kültürü Araştırma Enstutüsü,

Pamuk Ş. (1988). 100 soruda Osmanl1-Türkiye iktisadi tarihi. 1500-1914. İstanbul. Gerçek yayınevi,

Quataert D. (1983). Social disintegration and popular resistance in the Ottoman Empire 1881-1908. New York: New York University Press,

Rausas P. (1902). Le régime des capitulations dans l'Empire ottoman. Paris: Arthur Rousseau,

Rifat Önsoy. (1988). Tanzimat Dönemi Osmanli Sanayi ve sanayileşme politikasi. Ankara, Türkiye Iş Bankasi Kültür Yayinlari.

Recueil D'actes Internationaux de L'Empire Ottoman. Recueillis et Publies par Gabriel Effendi Noradounghian. (1978). Liechtenstein: Kraus,. T. 4

Sait Açba, (2004). "Osmanlı Devleti’nin Dış Borçlanmasıı", Ankara.

Takan, M. (2001). Bankacılık: Teori, Uygulama ve Yönetim. Ankara. Nobel Yayın Dağıtım.

Thobie J. (1973). Les es interets économiques financiers et politiques français dans la partie asiatique de L'Empire Ottoman de 1895 a 1914 Lille: UP,

Yılmaz, B. E. (2002). Osmanlı İmparatorluğu'nu dış borçlanmaya iten nedenler ve ilk dış borç. // Akdeniz İ.İ.B.F. Dergisi (4): S. 186-198. 